\title{
Az agrár-élelmiszer gazdaság üzleti kapcsolataiban szereplő információs és kommunikációs technológiák (IKT) alkalmazásának vizsgálata.
} Investigation of information and communication technologies (ICT) usage in the business relations of the agri-food economy.

\author{
S. BOROS-PAPP ${ }^{1}$, L. VÁRALLYAI ${ }^{2}$ \\ ${ }^{1}$ Debreceni Egyetem, Gazdaságtudományi Kar, Alkalmazott Informatika és Logisztika Intézet, \\ papps@hotmail.hu \\ 2Debreceni Egyetem, Gazdaságtudományi Kar, Alkalmazott Informatika és Logisztika Intézet, \\ varallyai.laszlo@econ.unideb.hu
}

Absztrakt. A kis- és középvállalkozások Európa gazdaságának a motorjai. Ezt bizonyítja a 2000-ben elfogadott Európai Kisvállalati Charta is, valamint az, hogy a szektor több mint 90 millió embert foglalkoztat. Hatékony müködésükhöz, versenyképességük megtartásához megfelelő információs és kommunikációs technológia ellátottság elengedhetetlen. Termelékenységük akadálytalan növekedése szempontjából ezen technológiákat tudniuk kell megfelelóen alkalmazniuk. Tanulmányunk célja a magyar KKV szektor regionális IKT ellátottságának felmérése és összehasonlítása az EU tagállamokkal.

Abstract. Small and medium-sized enterprises are the engines of Europe's economy. This is demonstrated by the European Small Enterprises Charta, adopted in 2000, and by the fact that this sector employs more than 90 million people. Appropriate information and communication technology is essential to maintain their ability to function effectively and competitively. They need to know how to use these technologies for their smoot growth in productivity. The purpose of our study is to assess the regional ICT penetration of the Hungarian SME sector and compare this to that of the EU Member States.

\section{Bevezetés}

Az élelmiszerszektor egyre inkább egy szorosan összefüggő rendszerré válik, komplex kapcsolatok egész hálózatával. Ennek következménye, hogy az ellátási láncok igen összetettek, rengeteg partnerségi, együttműködési formára és információs kapcsolatra épülnek. A lánctagok közötti információáramlás minősége pedig hatással lehet a láncok hosszára és összetettségére, valamint a készletszintek nagyságára is. 
Az információs és kommunikációs technológiák (IKT) egyre nagyobb szerepet töltenek be az ellátási lánc menedzsmentben. Az üzleti kapcsolatokban megkerülhetetlen a használatuk, de annak a vállalkozás működésére gyakorolt hatása csak tudományos igényességű vizsgálattal határozható meg.

A tanulmány fó témája a magyar KKV szektor regionális IKT ellátottságának felmérése és összehasonlítása az EU tagállamokkal. Vizsgálataink jelen fázisában szekunder adatokra támaszkodunk (KSH és Eurostat). Az elemzésnél 2015-2016-os adatokat használtunk fel, mivel jelen pillanatban ezek a legfrissebb adatok, amelyek rendelkezésre állnak. A következtetések levonásához felhasználtuk a szakirodalom hivatkozott forrásait is.

\section{A KKV-k helyzete, gazdasági szerepe}

A kis- és középvállalkozások (KKV) Európa és hazánk gazdaságának a motorjai. Ezt hangsúlyozza a 2000-ben elfogadott Európai Kisvállalati Charta [4] is. Egyedi jellegüket a nagyobb rugalmasság, a jobb innovációs képesség, az alacsonyabb fix költségek, a kevesebb piaci erő és a kevesebb tőke adják [10]. Döntéshozatalukra jellemző, hogy intuitív és strukturálatlan jellegű [5].

Mint minden vállalkozásnak, a KKV-nak is a legfőbb célja a versenyképesség növelése. Amennyiben egy vállalkozás hosszú távon is versenyképes akar maradni, szövetkeznie kell, hogy a tudáshoz és a technológiai eszközökhöz hozzájusson [12].

2014-ben a magyar vállalkozások 99,8\%-át a KKV-k adták, melyek a foglalkoztatottak 69,8\%-ának biztosítottak munkahelyet [11]. Holicza [6] szerint a KKV-kat érintő legnagyobb problémák a következők:

- az oktatás nem készít fel a vállalkozásindításra,

- a finanszírozás hiányos,

- a siker elmaradása esetén a veszteségek komolyak,

- az adminisztrációs eljárások bonyolultak.

Ehhez a felsoroláshoz hozzátartozik, hogy a Debreceni Egyetem Gazdaságtudományi Karán elindult több évvel ezelőtt (2009) a Vállalkozásfejlesztés mesterszak, aminek egyik célja éppen az első pontban felsorolt hiányosság csökkentése.

Az adminisztratív terhek csökkentésének céljából „A kis- és középvállalkozások fejlesztésének stratégiája 2014-2020” támogatja a „Gondolkozz előbb kicsiben!” elvet [3]. A KKV-k problémái közé sorolhatjuk a továbbképzés valamint az informatikai ismeretek hiányát [1].

\section{A KKV-k IKT használata}

A legtöbb vállalat számára alapvető kihívás az IKT rendszerek használata. A vállalatok többségének nincsenek megfelelő ismeretei az IKT lehetőségeiről. Így arról sem, hogy ez elég összetett rendszer, melynek egyik sarkalatos pontja az internetkapcsolat minősége (elérhetősége, sebessége és sávszélessége). 


\subsection{Internetkapcsolat}

Az Európai Unió internetkapcsolattal rendelkező vállalkozásainak aránya az elmúlt években stagnál, 97\% (1. ábra). Öt ország mondhatja el magáról, hogy minden vállalkozása rendelkezik (valamilyen sebességü) internettel:

- Dánia

- Finnország

- Hollandia

- Litvánia

- Luxemburg

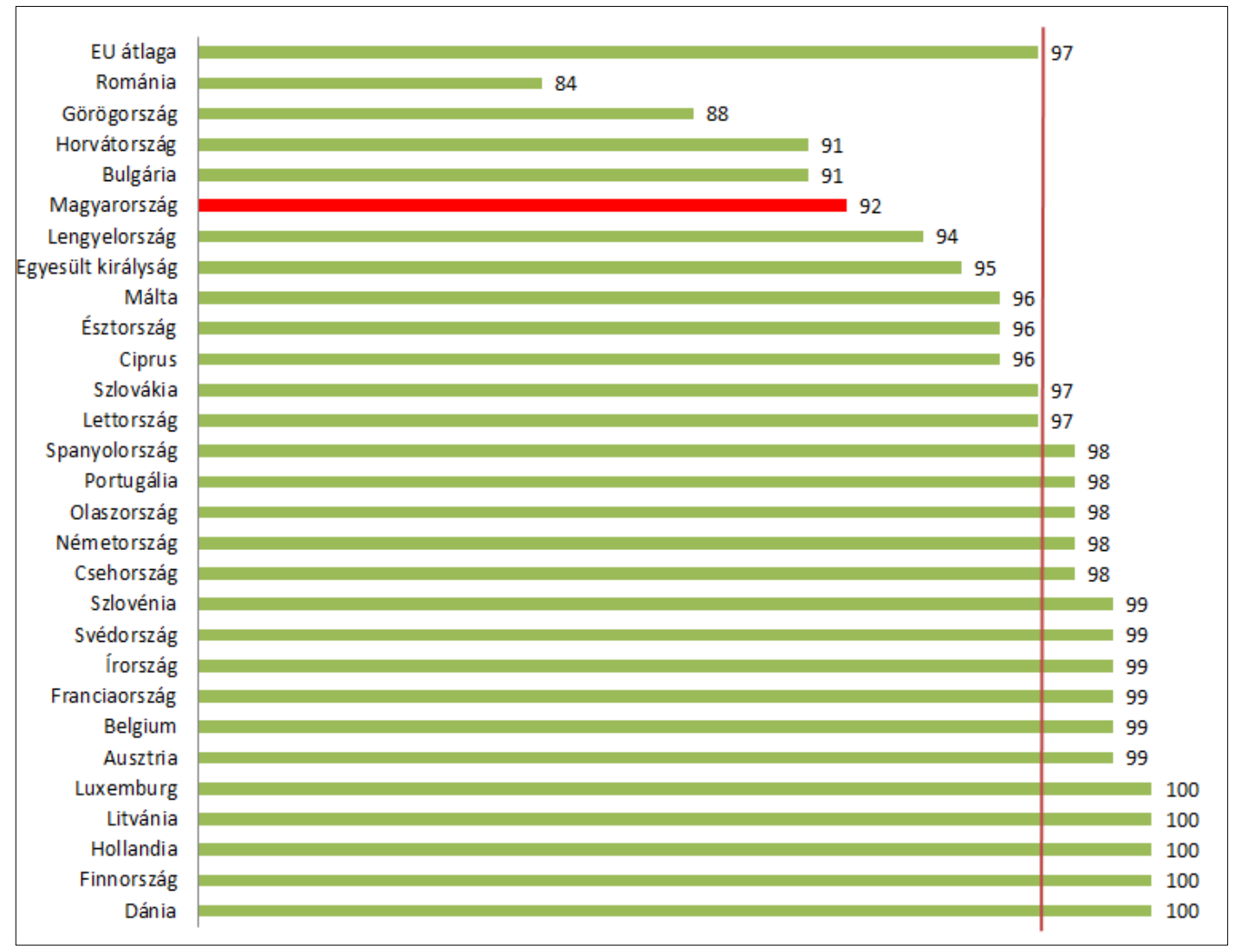

1. ábra: Internet kapcsolattal rendelkezô vállalkozások aránya az EU tagállamokban (Forrás: Saját szerkesztés az EUROSTAT, 2016 adatai alapján)

Magyarország 5 százalékponttal (92\%) marad le az EU átlagtól, a legkisebb aránnyal pedig Románia rendelkezik (84\%). Mint ahogy az ábrán is látszik hazánk ebből a szempontból az utolsó kvartilisben foglal helyet.

Regionális szinten vizsgálva a hazai vállalkozásokat, a dunántúli régiók dominanciája rajzolódik ki, a legelmaradottabb az Észak-Alföldi, de még ott is 89,7\% ez az érték, tehát nincsenek kardinális különbségek regionális szinten [9]. 


\subsection{Vállalkozások honlap ellátottsága}

Vessünk egy pillantást a vállalkozások honlap ellátottságára. Az uniós tagállamokban a honlappal rendelkező vállalkozások aránya 77\% (2. ábra). Finnország (95\%) és Dánia (93\%) dominanciája itt is szembetűnő. Az szinte minden országban elmondható, hogy vannak olyan KKV-k, amelyek egyszerűen nem érzik szükségét egy honlap meglétének, mivel már korábbról rendelkeznek olyan partneri körrel, amely biztosítja számukra a szükséges profitot. Ők úgy gondolják, hogy a befektetés a honlapba, nem biztos, hogy megtérülne számukra.

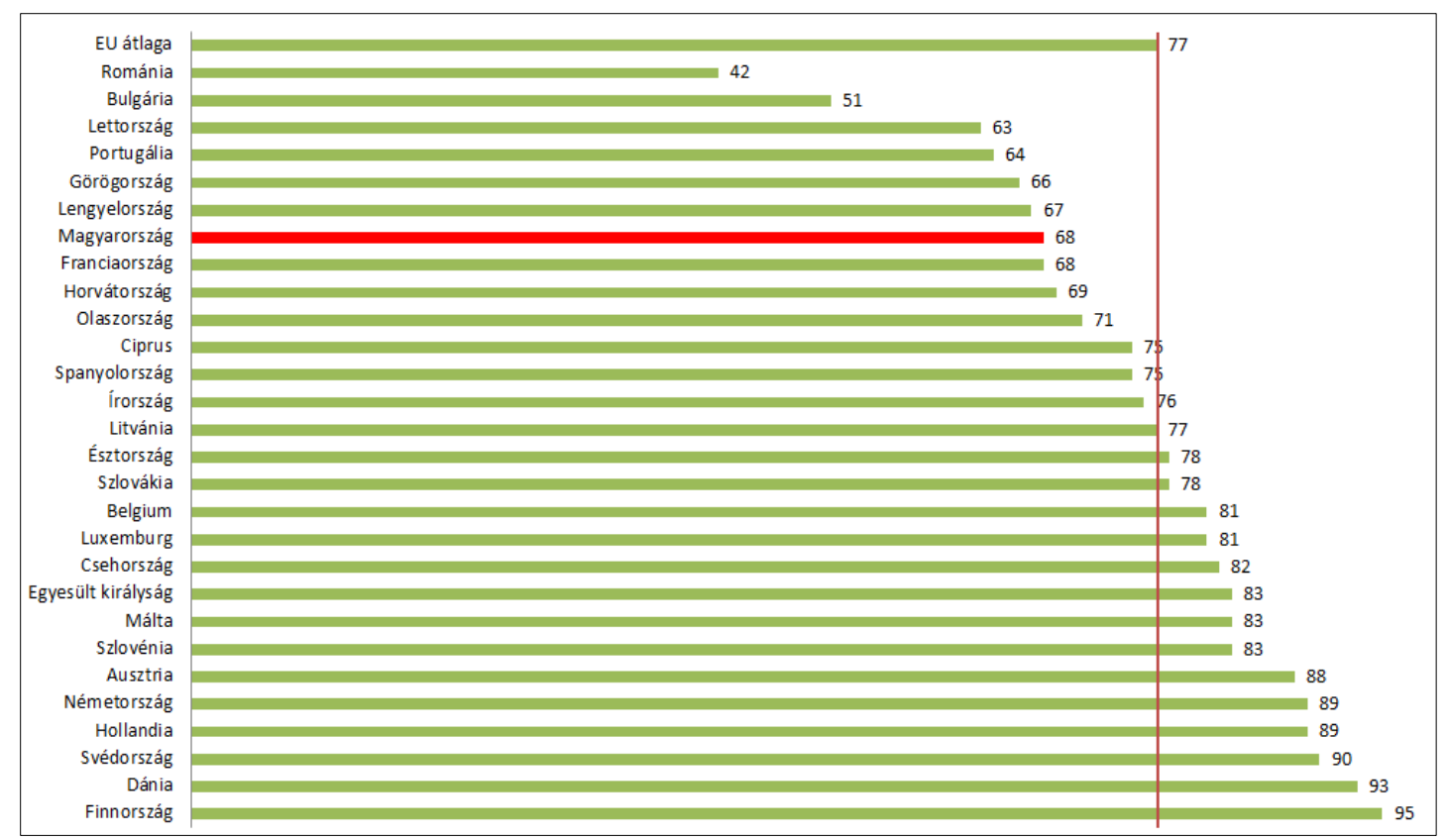

2. ábra: Honlappal rendelkező vállalkozások aránya az EU tagállamokban

(Forrás: Saját szerkesztés az EUROSTAT, 2016 adatai alapján)

A legelmaradottabb ebből a szempontból is Románia (42\%), míg a magyar vállalkozások 68\%-a múködtet weboldalt vagy portálrendszert. Ezzel az aránnyal az utolsó kvartilis tetején, illetve a harmadik kvartilis alján vagyunk Franciaországgal közösen.

Az ország régióit vizsgálva még nagyobb a szakadék, mint az internet tekintetében, hiszen a legfejlettebb Közép-Magyarországi (74,3\%) és a legelmaradottabb Észak-Alföldi (58,2\%) régió között kb. 16\%-os különbség mutatkozik [9].

\subsection{Letöltési sebesség}

$\mathrm{Az}$ internethasználat gyakoriságára és minőségére nagy hatással van az igénybe vehető Internet elérési sebesség. Azt is meg kell említenünk, hogy a szélessávú kapcsolatok használati aránya növekvő tendenciát mutat [8], persze ez erősen helyfüggő (vannak olyan helyek, ahol nem éri meg a szélessávú Internetelérést kiépíteni, itt természetesen más megoldást kell alkalmazni pl. mobilnet).

A kisvállalkozások (10-49 fó) körében, az átlagosnak és elfogadhatónak mondható 10-30 Mbit/s közötti kapcsolattal a vállalkozások 36,1\%-a rendelkezik (3. ábra). Ugyanakkor még sajnos mindig 
nagyon elterjedt a $10 \mathrm{Mbit} / \mathrm{s}$ alatti letöltésű sebességtípus is (33\%). A szélessávú Internet kapcsolatot ott érdemes kiépíteni, ahol megfelelő számú felhasználó koncentráltan él (ebből a szempontból nagyobb városok lakótelepei prioritást élveznek).

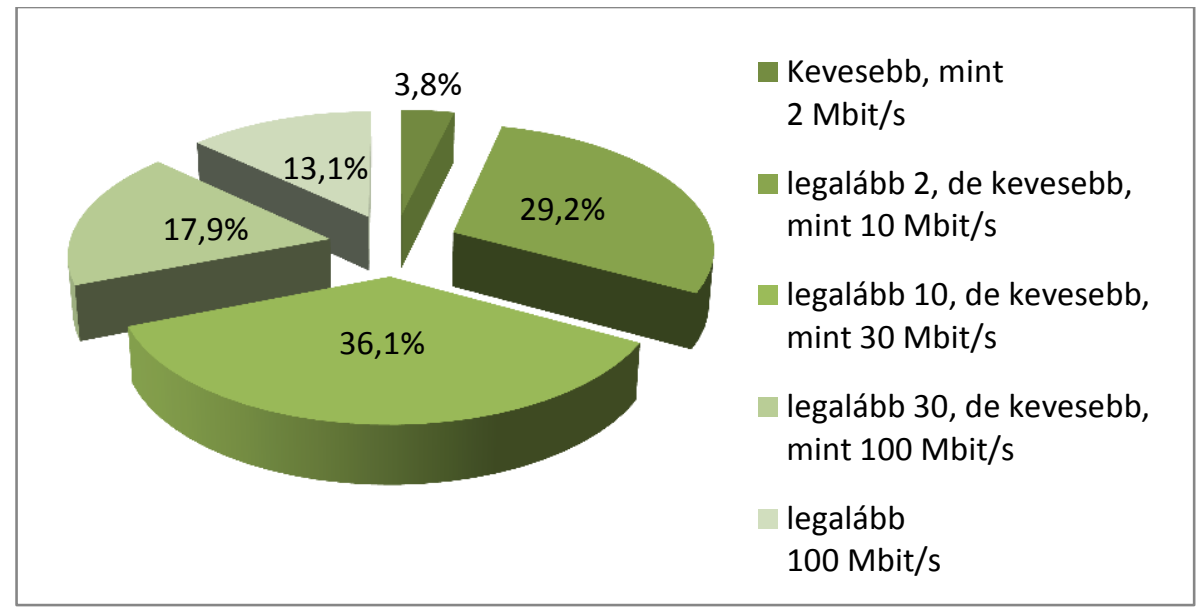

3. ábra: Az internetkapcsolattal rendelkező hazai kisvállalkozások megoszlása letöltési sebesség szerint. (Forrás: Saját szerkesztés a KSH, 2016 adatai alapján)

A középvállalkozások (50-249 fó) helyzete jobbnak mondható. Esetükben már háttérbe szorulnak a 10 Mbit/s alatti sebességek, arányuk 23,4\% (4. ábra). A létszámra való tekintettel, a zavartalan munkavégzés céljából nagyobb hangsúlyt fektettek a $30 \mathrm{Mbit} / \mathrm{s}$ feletti sebességre $(40,8 \%)$.

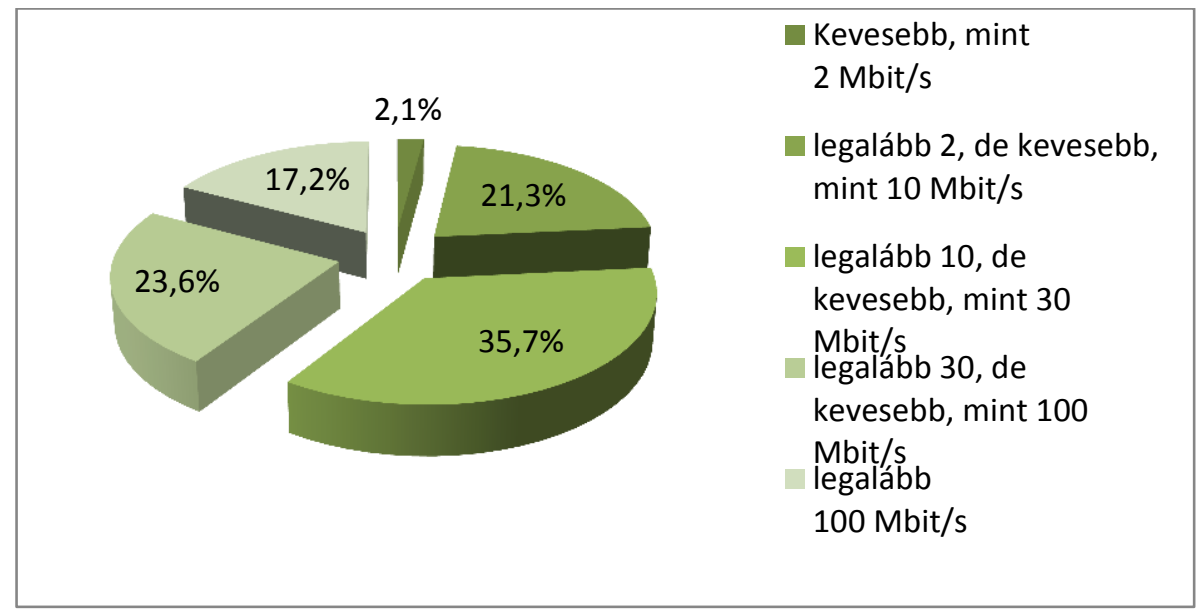

4. ábra: Az internetkapcsolattal rendelkező hazai középvállalkozások megoszlása letöltési sebesség szerint. (Forrás: Saját szerkesztés a KSH, 2016 adatai alapján)

Azt az adatok alapján bátran kijelenthetjük, hogy az internetkapcsolatok regionális eloszlásában kiemelkedő különbségek nincsenek (5. ábra), leszámítva Közép-Magyarország és Dél-Dunántúl különbségeit. 
DOI: 10.21791/IJEMS.2018.4.3.

\begin{tabular}{|c|c|c|c|c|c|c|c|c|c|c|c|}
\hline Dél-Alföld & 2,9 & \multicolumn{3}{|c|}{33,5} & \multicolumn{4}{|c|}{37,0} & 15,8 & 10 &, 8 \\
\hline Észak-Alföld & 4,2 & \multicolumn{3}{|c|}{32,9} & \multicolumn{4}{|c|}{32,8} & 19,4 & 10 &, 6 \\
\hline Észak-Magyarország & 2,6 & \multicolumn{3}{|c|}{32,2} & \multicolumn{4}{|c|}{38,6} & 15,6 & 11, & 0 \\
\hline Dél-Dunántúl & 3,6 & \multicolumn{3}{|c|}{25,8} & \multicolumn{4}{|c|}{48,6} & \multicolumn{2}{|c|}{15,2} & 6,8 \\
\hline Nyugat-Dunántúl & 4,0 & \multicolumn{3}{|c|}{29,6} & \multicolumn{4}{|c|}{39,7} & \multicolumn{2}{|c|}{16,4} & 10,1 \\
\hline Közép-Dunántúl & 6,1 & & 28,5 & & & $34, \subseteq$ & & & 18,1 & 12, & \\
\hline \multirow[t]{2}{*}{ Közép- Magyarország } & 2,9 & \multicolumn{2}{|c|}{ 24,1 } & \multicolumn{4}{|c|}{33,5} & 21,4 & & \multicolumn{2}{|l|}{18,2} \\
\hline & $\%$ & $10 \%$ & $20 \%$ & $30 \%$ & $40 \%$ & $50 \%$ & $60 \%$ & $70 \%$ & $80 \%$ & $90 \%$ & $100 \%$ \\
\hline \multicolumn{5}{|c|}{ legalább 10, de kevesebb, mint 30 Mbit/s } & \multicolumn{7}{|c|}{ legalább 30, de kevesebb, mint 100 Mbit/s } \\
\hline \multicolumn{12}{|l|}{ legalább } \\
\hline
\end{tabular}

5. ábra: Letöltési sebesség megoszlása régiók szerint.

(Forrás: Saját szerkesztés a KSH, 2016 adatai alapján)

\subsection{Felhő alapú eszközhasználat}

A felhő alapú szolgáltatások lényege, hogy nem szükséges a vállalkozásoknak komoly informatikai tudással rendelkezni valamint nem kell külön informatikai szakembert vagy szakembereket alkalmazniuk. A megtakarított bérköltségekből felszabaduló pénzeszközöket így szolgáltatásvásárlásra tudják fordítani, amely sok esetben alacsonyabb költséget jelent számukra. A felhő alapú szolgáltatásoknak számos előnye van, a versenyképesség növekedése mellett a hatékonyságot is növeli, megfelelő alkalmazás mellett az adatvédelem is növekedhet. A felhő alapú adatforgalom napjainkban folyamatosan növekszik, mivel a gazdasági verseny megköveteli, hogy a vállalkozások egyre gyorsabban reagáljanak a környezeti változásokra.

Három alapvető felhőalapú szolgáltatásmodellt ismerünk [2]:

- IaaS, infrastruktúra mint szolgáltatás,

- PaaS, platform mint szolgáltatás,

- SaaS, szoftver mint szolgáltatás.

IaaS (Cloud Infrastructure as a Service): A felhő alapú szolgáltatások alapja. A vállalkozások virtuális környezetben férnek hozzá a tárhelyekhez, telepített alkalmazásokhoz, azonban a karbantartást a felhasználóknak kell elvégezni. 
PaaS (Cloud Platform as a Service): A vállalkozás által használt alkalmazásokat a szolgáltató telepíti egy általa kiválasztott programnyelven a felhő hálózatba. Ebben az esetben is a karbantartás a felhasználó feladata.

SaaS (Cloud Software as a Service): A szolgáltatói alkalmazások a felhő infrastruktúrában futnak, webböngészőkön keresztül érhetőek el. Nem igényelnek nagymértékű beruházást, azonnal használhatóak.

A magyar kis- és középvállalkozások felhő alapú szolgáltatás igénybevételét a 6. ábra jól szemlélteti.

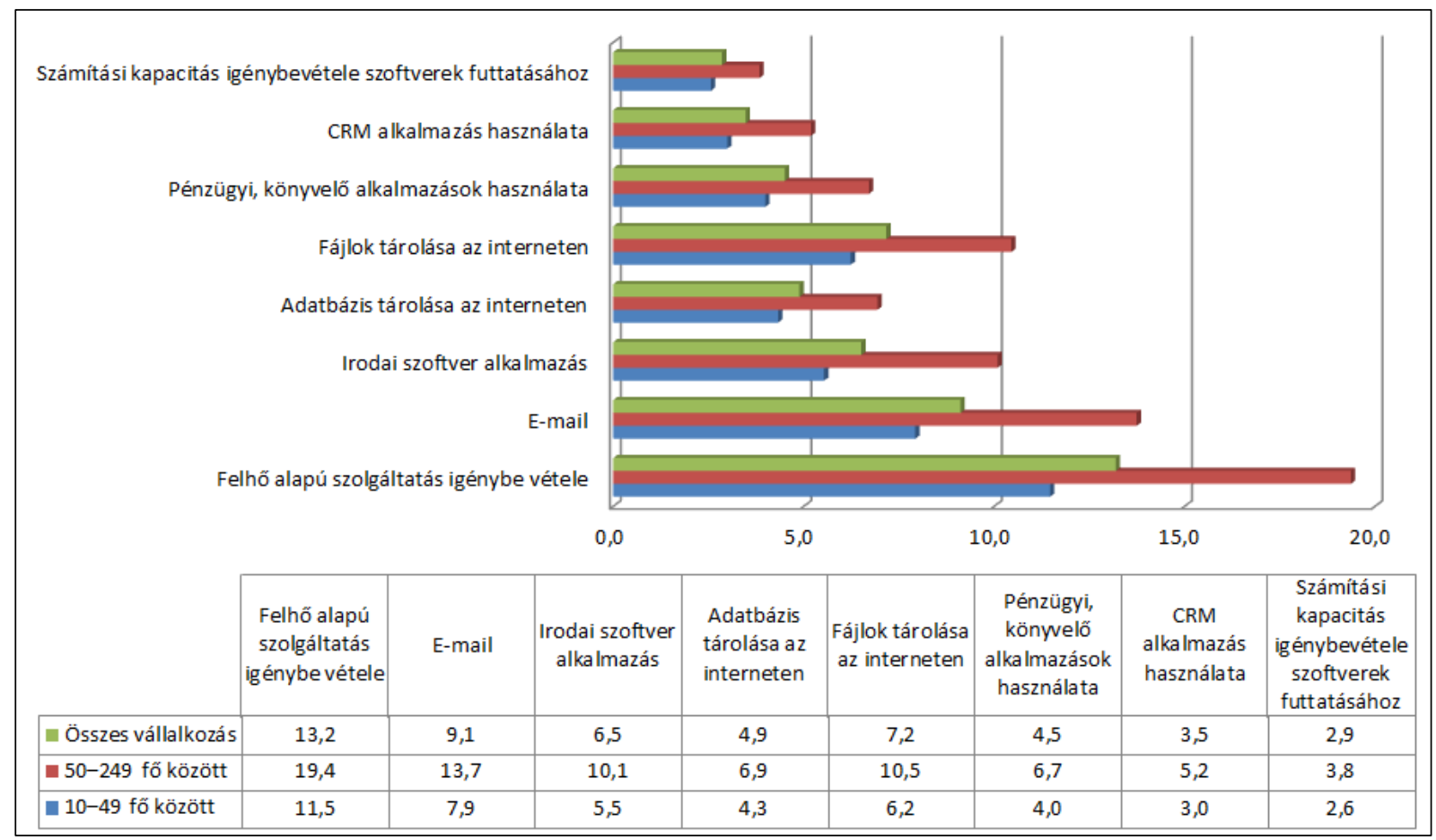

6. ábra: Felhő alapú eszközök használata létszám kategóriánként (internetet használó vállalkozások \%-ban).

(Forrás: Saját szerkesztés az KSH, 2016 adatai alapján)

A 6. ábrán jól látható, hogy a középvállalkozások (50-249 fő) minden szempontot figyelembe véve nagyobb hangsúlyt fektetnek a felhő alapú szolgáltatások alkalmazására.

Magyarországon tavaly jelent meg kifejezetten a mikro-, kis és középvállalkozások részére a "GINOP3.2.4-8.2.4-16 Felhőalapú (IaaS, PaaS, SaaS) vállalati szolgáltatások, IKT megoldások fejlesztésének és piaci bevezetésének támogatása" című felhívás [7]. Célja az olyan nemzetgazdaságilag fontos szektorok támogatása, amelyeknek informatikai ellátottságában lemaradás tapasztalható, pl.: mezőgazdaság, élelmiszeripar (TEÁOR'08 C 29-30). Egyedül a Közép-Magyarország régió (Budapest, Pest megye) nem támogatott. A támogatási kérelem benyújtására még jelenleg is van lehetőség (2017. február 8-tól 2019. február 8-ig). 


\section{Összefoglalás}

Digitális fejlettségről annak mértékében beszélhetünk, hogy a vállalkozások milyen arányban élnek a digitális technológiák által kínált lehetőségekkel és előnyökkel.

A magyar KKV szektor IKT használat és alkalmazás szempontjából az összehasonlítási területeken elmaradásban van az EU átlagtól, ezt tükrözi a megvizsgált internetkapcsolat és holnap ellátottság is. Az utolsó kvartilisből való kilépéshez, és a felzárkózáshoz elengedhetetlen, hogy az alapvető infokommunikációs eszközöket és szolgáltatásokat megfelelően vegyék igénybe.

Az IKT eszközök által nyújtott lehetőségeket megfelelően kihasználva a versenyképesség megtartása vagy fokozása könnyebben elérhető. A vállalatok IKT-eszköz használatától és alkalmazásától nagymértékben függ az IT fejlettség mértéke.

Az adatok és a szakirodalom alapján egyértelműen arra következtethetünk, hogy az informatikában lemaradó, elhanyagolt szektorokban és régiókban az internet nyújtotta lehetőségek kihasználtsága alacsony, de mégis minden vállalatra elmondható, hogy az adatrobbanás jelenséghez alkalmazkodni próbálnak, miközben új piaci tevékenységtípusok, szerepek jönnek létre.

\section{Hivatkozások}

[1] A. Chikán - E. Czakó - Á. Wimmers (2014) Kilábalás göröngyös talajon. Gyorsjelentés a 2014 évi kérdő́ves felmérés eredményeiről. Budapesti Corvinus Egyetem, Versenyképességi Kutató Központ

[2] C. Harding (2011) Cloud Computing for Business - The Open Group Guide, The Open Group. Van Haren Publishing.

[3] EC Vállalkozáspolitikai és Ipari Főigazgatóság (2016) 2015 évi SBA tájékoztató Magyarország. $1-17$.

[4] http://ec.europa.eu/docsroom/documents/16344/attachments/15/translations/hu/renditio ns/native

[5] European Commission (2004) Kisvállalkozások Európai Chartája 2004. Luxemburg. Az Európai Közösségek Hivatalos Kiadványainak Hivatala.

[6] A. Gilmore - D. Carson - K. Grant (2001) SME marketing inpractice. Marketing Intelligence\&Planning, 19 (1) pp. 6-11.

[7] P. Holicza (2016) A magyar KKV szektor helyzete nemzeti és nemzetközi szinten. Vállalkozásfejlesztés a XXI. században. Budapest. pp. 147-162. ISBN 978-615-5460-78-4

[8] https://www.palyazat.gov.hu/ginop-324-824-16-felhalap-iaas-paas-saas-vllalati-szolgltatsokikt-megoldsok-fejlesztsnek-s-piaci-bevezetsnek-tmogatsa-1

[9] KSH (2016) Az infokommunikációs technológiák és szolgáltatások helyzete Magyarországon : https://www.ksh.hu/docs/hun/xftp/idoszaki/ikt/ikt16.pdf

[10] KSH (2016) Infokommunikációs (IKT-) eszközök és használatuk a vállalati (üzleti) szektorban : http://www.ksh.hu/docs/hun/xftp/idoszaki/ikt/ikt16_1.xls 
[11] J. A. Motwani - J. J. Jiang - A. Kumar (1998) A comparative analysis of manufacturing practices of small vs. large Western Michigan organizations. Industrial Management \& Data Systems, 98 (1) pp. 8-11.

[12] Nemzetgazdasági Minisztérium (2016) KKV Évkönyv. A kis- és középvállalkozások helyzete Magyarországon 2014. Budapest. pp. 1-109.

[13] A. Nyiri - D. Szakály (2010) Absorb meter. 89 p. ISBN: 9789638834522 